UDC 343.152 .9

LBC 67.410.206

\title{
THE CRIMINAL PROCEDURE EXPENSES RELATING TO OTHER EXPENSES
}

\author{
Vadim N. Perekrestov \\ Judicial District no. 47, Svetloyarsky District of Volgograd Region, Russian Federation
}

Natalya A. Solovyeva

Volgograd State University, Volgograd, Russian Federation

Introduction. The submitted article is devoted to the actual problems connected with definition of other expenses relating to criminal procedure expenses, but which are specifically not specified in Art. 131 of theCPC of the RF. Purpose is to improve legislation regulating criminal procedure expenses. Methods include comparative-legal, systemic, analysis and synthesis, functioned methods. Results. Fixing in item 9 of the p. 2 of Art. 131 of the CPC of the RF of other expenses gives the chance for reference to number of procedural expenses of any expenses connected with criminal proceeding as the list of types of procedural expenses is not exhaustive. It is offered to consider as other procedural expenses the money spent for carrying out operational search actions, the material losses suffered as a result of carrying out investigative actions, the victim, the witness and other persons involved in criminal trial; compensation of cost of the damaged property at a lawful search; expenses of the parties on the legal aid given by lawyers under the agreement. Conclusions. The author suggests to make changes in the CPC of the RF in item 4 ofh 2 Art. 131 KRF Unitary Enterprise, having specified that the remuneration paid to the expert for execution by it during criminal trial of the duties as an office task does not belong to procedural expenses.

Key words: criminal procedure costs, expenses, other expenses, federal budget, lawyer for the agreement.

\section{УГОЛОВНО-ПРОЦЕССУАЛЬНЫЕ ИЗДЕРЖКИ, ОТНОСЯЩИЕСЯ К ИНЫМ РАСХОДАМ}

\author{
Вадим Николаевич Перекрестов \\ Судебный участок № 47, Светлоярский район Волгоградской области, Российская Федерация
}

Наталья Алексеевна Соловьева

Волгоградский государственный университет, Волгоград, Российская Федерация

\footnotetext{
Введение: представленная статья посвящена актуальным проблемам, связанным с определением иных расходов, относящихся к уголовно-процессуальным издержкам, но конкретно не указанных в ст. 131 УПК РФ. В связи с этим в работе поставлена цель совершенствования законодательства в части регламентации уголовно-процессуальных издержек. Для достижения поставленной цели были использованы методы научного познания: сравнительно-правовой, системный, анализ и синтез, метод историзма, функциональный. Результаты: закрепление в п. 9 ч. 2 ст. 131 УПК РФ иных издержек дает возможность для отнесения к числу процессуальных издержек любых затрат, связанных с производством по уголовному делу, поскольку перечень видов процессуальных издержек не является исчерпывающим. Предлагается в качестве иных процессуальных издержек рассматривать денежные средства, израсходованные на проведение оперативно-розыск응 ных мероприятий, материальных потерь, понесенных в результате проведения следственных действий, потерпевшим, свидетелем и иными лицами, вовлеченными в уголовное судопроизводство; возмещение стоимости поврежденного имущества при законном обыске; расходы сторон на юридическую помощь, оказываемую адвокатами по соглашению. Выводы: предлагается внести изменения в п. 4 ч. 2 ст. 131 УПК РФ, указав, что вознаграждение, выплачиваемое эксперту за исполнение им в ходе уголовного судопроизводства своих обязанностей в порядке служебного задания, к процессуальным издержкам не относится.

Ключевые слова: уголовно-процессуальные издержки, расходы, иные издержки, федеральный бюджет, адвокат по соглашению.
} 


\section{Introduction}

The scientific literature highlights the problems of defining and collection of criminal procedural outlays slightly or does not cover them at all. The scientific indifference to the institution of procedural outlays seems to be unfounded because there are problems of its legal regulations which cause ambiguity in the use of rules in judicial practice.

As provided for by first part of Article 131 of the Criminal-Procedure Code of the Russian Federation, the procedural outlays shall be spending connected with the proceedings on the criminal case, which shall be recompensed from the funds of the federal budget or from the means of the parties in the criminal court proceedings.

In this context, a quiet thorough definition of procedural outlays seems to be the one formulated by the Constitutional Court of the Russian Federation in the Definition of December 16, 2008 No. 1036-O-P “On complaint by citizen Aleksey A. Baykov about the breach of his constitutional rights stipulated in Item 5 of the fourth part of Article 56, in the first part of Article 81, Item 2 of the second part of Article 82, Articles 119 and 131 of the Criminal-Procedure Code of the Russian Federation": "the money for recompensation of the necessary and reasonable expenses, lost income and also remuneration and payments which shall be paid out for the private persons and artificial persons involved in the criminal court proceedings as a party or engaged in the solution of the goals in a different way" [5].

\section{The difference from the statements of the Plenum of the Supreme Court of the Russian Federation}

The Criminal-Procedure Code of the Russian Federation changed considerably the legal nature of court expenses. All this spending used to be considered as expenses of court proceedings, but after July 1, 2002 they have being determined as procedural outlays. The radical difference between these two notions is that expenses of court proceedings used to be considered as all material expenses of the government (both direct and indirect) for struggle against criminality including spending on judicial authorities and law-enforcement authorities and also finance for the discharge of their duties. Whereas procedural outlays are spending of the federal budget paid out only for the arrangement of the criminal court proceedings on all the criminal cases which are examined by the authoritative bodies; that is why the spending on them are not included in this type of outlays [3].

Thus, according to the new Plenum of the Supreme Court of the Russian Federation, the other spending connected with criminal proceedings include, in particular, expenses directly connected with collecting and examination of demonstrative proof stipulated by the CriminalProcedure Code of the Russian Federation (for example, the sums paid out to the teacher, psychologist or other persons to cover their expenses incurred during taking part in the conducting of investigative actions). Besides, they include the sums paid out by the victim to the legal representative which are proved by the relevant documents, the spending of the other interested persons at any stage of the criminal proceedings if they are necessary and reasonable [6].

The radical difference from the statements of the Plenum of the Supreme Court of the Russian Federation presented in the Resolution of September 26, 1973 No. 8, which regulates these issues, is in the statement in the second paragraph of the Item being commented. So, now the Plenum does not refer to the procedural outlays the sums paid out for compensation for damages caused by illegal actions and resolution of the inquirer, the investigator, the public prosecutor in accordance with Parts Three and Five of Article 133 of the Criminal-Procedure Code of the Russian Federation. To such procedural outlays shall be referred, for example, the sums paid out for compensation for damages caused as a result of illegal confiscation of property and detainer as the demonstrative proof, and also expenses connected with the recompensation of the cost of things damaged or destructed due to the investigative experiments or expertise. As such expenses are not stipulated by the Law of Criminal Procedure, they shall be recompensed according to the civil law proceedings in accordance with the fifth part of Article 133 of the CriminalProcedure Code of the Russian Federation [2]. According to Article 131 of the CriminalProcedure Code of the Russian Federation, 
"damage caused due to the unjustified confiscation and detainer of property by the inquirer or the court as the demonstrative proof, can be reicompensated to the owner of property or another legal proprietor if there are the conditions stipulated by Articles 1064 and 1069 of the Civil Code of the Russian Federation, and shall not be included in the expenses of court proceedings" [5].

So, from year to year, one of the typical mistakes in the court practice is the wrong use of Item 4 of Part Two of Article 131 of the CriminalProcedural Code of the Russian Federation, and also Item 7 of Part Two of Article 131 of the Criminal-Procedural Code of the Russian Federation, that leads to change of judgments and exclusion from them the directions to exact from the convict procedural outlays for the expertise to the federal budget [4].

\section{The course of the proceedings on the criminal case}

In accordance with Item 4 of the second part of Article 131 of the Criminal-Procedure Code of the Russian Federation, the remuneration, paid out to the expert for the discharge of his duties in the course of the criminal court proceedings when these duties were discharged by him under official orders is not referred to procedural outlays.

According to the statements in Items 4 and 7 of the second part of Article 131 of the CriminalProcedure Code of the Russian Federation, and also the statements of the Federal Law of May 31, 2001 No. 73 "About the state court-expert activity in the Russian Federation" [4], the remuneration, paid out to the expert for the discharge of his duties in the course of the criminal court proceedings when these duties were discharged by him under official orders shall not be referred to procedural outlays and shall not be exacted from the convicts.

In accordance with the Federal Law of May 31,2001 No. 73 the activity of the state court and expert authorities, expert departments of the federal executive power bodies, including expert departments of the internal affairs bodies of the Russian Federation is financed from the funds of the federal budget. The activity of the state court and expert authorities, expert departments of the federal bodies of the executive power of the Russian Federation is financed from the funds of the entities of the Russian Federation.
It is reasonable to agree with Professor A.R. Belkin who considers that "it would be more logical to make the dichotomy in another way, distinguishing the case when the expert, specialist or interpreter acts as the legal representative of the expert institution (organisation) or in private capacity. It comes natural to change the order of Items 4 and 7 vice versa", whereof to unite Items 4 and 7 of the second part of Article 131 of the Criminal-Procedure Code of the Russian Federation stating that "the sums spent for carrying out the forensic medical expertise at the expert institutions and / or as the remuneration to the expert, specialist, interpreter or teacher for the discharge of their duties in the course of the criminal court proceedings if the activity of such institutions is not recompensed from the funds of the federal budget" [1].

According to Item 9 of the second part of Article 131 the Criminal-Procedure Code of the Russian Federation the list of types of procedural outlays is not thorough.

It appears that to the other procedural outlays shall be referred the money paid out for investigative activities (for example, the sums paid out for buying narcotic drugs in the process of evidential purchase); material losses suffered as a result of investigative actions by the victims, witness or the other parties involved in the criminal proceedings (for example, damage of the car in the process of investigative experiment); the sums paid out for lump sum allowances if loss (death), the bodily injuries or the other threat to the health of the person due to his involvement in the criminal proceedings (for example, if the person who took part in the investigative experiment has died ("extra")). That could be outlays, spending which shall be recompensed to the persons taking part in the interrogation (except the victims); compensation of the cost of the damaged property in the process of the search performed on the ground of an investigator's resolution; spending of the parties (the victim, the civil defendant and others) on searching and presenting of the demonstrative proof and; spending of the parties on legal assistance by the lawyers under agreement.

In accordance with Item 34 of the Resolution of the Plenum of the Supreme Court of the Russian Federation of June 29, 2010 No. 17 on the force of Part Three of Article 42 of the Criminal-Procedure Code of the Russian 
Federation to the victim shall be guaranteed the compensation for the outlays he has had to make in connection with his participation in the process of the preliminary investigation and of the trial, including the outlays on the representative, in conformity with the demands of Article 131 of the Criminal-Procedure Code of the Russian Federation. The court shall consider that these outlays approved by the relevant documents in conformity with Item 9 of the second part of Article 131 of the Criminal-Procedure Code of the Russian Federation refer to the other outlays made in the course of the proceedings on the criminal case which shall be exacted from the convicts or shall be recompensed from the funds of the federal budget (the first part of Article 132 of the Criminal-Procedure Code of the Russian Federation) [7].

At the same time, it should be taken into account that applying the clarification in Item 34 of the Federal Law of December 28, 2013 No. $432-\mathrm{FZ}$ the sums paid out to the victim to cover his expenses connected with the remuneration, paid out to the representative of the victim are separated in a certain type of procedural outlays (Item 1.1 of the second part of Article 131 of the Criminal-Procedural Code of the Russian Federation).

\section{Conclusions}

The outlays connected with the storage of the demonstrative proof, the sums paid for postal communications, and the outlays connected with the appearance of the suspect or the accused before the investigator and before the court shall not be referred to the procedural outlays as they shall be considered in the estimate of expenses of the investigative bodies and the court, and in the latter case shall not simply be recompensed as they are caused by the parties to criminal proceedings. However, in some cases the demonstrative proof shall be kept in another place. For example, if the stolen car had been delivered to a special transport organization for storage before the owner of the car was established the outlays connected with its storage shall be referred to procedural outlays.

Thus, the stipulation of the other outlays in Item 9 of the second part of Article 131 of the Criminal-Procedure Code of the Russian
Federation, gives an opportunity to refer to the procedural outlays any spending connected with the proceedings on the criminal case. This problem must be solved in terms of legislation by more thorough and detailed definition of the notion of the other spending or by expanding the list of procedural outlays in the second part of Article 131 of the Criminal-Procedure Code of the Russian Federation.

\section{REFERENCES}

1. Belkin A.R. Spornye voprosy ischisleniya protsessualnykh izderzhek $\mathrm{V}$ ugolovnom sudoproizvodstve [Controversial issues of calculation of procedural expenses in criminal trial]. Mirovoy sudya, 2013, no. 6. Access from reference legal system "KonsultantPlyus".

2. Kommentariy k postanovleniyam Plenuma Verkhovnogo Suda Rossiyskoy Federatsii po ugolovnym delam [Commentary to resolutions of Plenum of the Supreme Court of the Russian Federation on criminal cases]. Norma, 2014, pp. 347-348. Access from reference legal system "KonsultantPlyus".

3. Kommentariy k Ugolovno-protsessualnomu kodeksu Rossiyskoy Federatsii [Commentary to the Criminal Procedure Code of the Russian Federation]. Moscow, 2004, pp. 347-348.

4. Opredelenie VS RF ot 18.07.2011 № 1-Dp116; Postanovlenie Prezidiuma VS RF ot 21.03.2012 № 38-P12; Postanovlenie Prezidiuma VS RF ot 05.06.2013 № 30-P13PR; Postanovlenie Prezidiuma VS RF ot 19.03.2014 № 18-P14PR [Determination of the Supreme Court of the Russian Federation of July 18, 2011 no. 1-Dp11-6; Resolution of the Presidium of the Supreme Court of the Russian Federation of March 2012 no. 38-P12; Resolution of the Presidium of the Supreme Court of the Russian Federation of June 5, 2013 no. 30-P13PR; Resolution of the Presidium of the Supreme Court of the Russian Federation of March 19, 2014 no. 18-P14PR]. Access from reference legal system "KonsultantPlyus".

5. Opredelenie Konstitutsionnogo Suda RF ot 16.12.2008 № 1036-O-P "Po zhalobe grazhdanina Baykova Alekseya Alekseevicha na narushenie ego konstitutsionnykh prav punktom 5 chasti chetvertoy statyi 56 , chastyu pervoy statyi 81, punktom 2 chasti vtoroy statyi 82, statyami 119 i 131 Ugolovnoprotsessualnogo kodeksa Rossiyskoy Federatsii [Determination of the Constitutional Court of the Russian Federation of December 16, 2008 no. 1036-O-P "According to the complaint of the citizen Alexey Alekseevich Baykov on violation of his constitutional rights by point 5 of part 4 of art. 56, part 1 of art. 81, 
point 2 of part 2 of art. 82, art. 119 and 131 of the CPC of the Russian Federation]. Access from reference legal system "KonsultantPlyus".

6. Postanovlenie Plenuma Verkhovnogo Suda RF ot 19.12.2013 № 42 "O praktike primeneniya sudami zakonodatelstva o protsessualnykh izderzhkakh po ugolovnym delam" [The resolution of Plenum of the Supreme Court of the Russian Federation of December 19, 2013 no. 42 "About practice of application by courts of the legislation on procedural costs for criminal cases"]. Access from reference legal system "KonsultantPlyus".

7. Postanovlenie Plenuma Verkhovnogo Suda RF ot 29.06.2010 № 17 (red. ot 09.02.2012) "O praktike primeneniya sudami norm, regla- mentiruyushchikh uchastie poterpevshego $v$ ugolovnom sudoproizvodstve" [The resolution of Plenum of the Supreme Court of the Russian Federation of June 29, 2010 no. 17 (ed. of February 9, 2012) "About practice of application by courts of the norms regulating participation of the victim in criminal trial"']. Access from reference legal system "KonsultantPlyus".

8. Federalnyy zakon ot 31.05.2001 № 73-FZ (red. ot 08.03.2015) "O gosudarstvennoy sudebnoekspertnoy deyatelnosti v Rossiyskoy Federatsii" [The Federal Law of May 31, 2001 no. 73-FL (ed. of March 8, 2015) "About the state judicial and expert activity in the Russian Federation"]. Access from reference legal system "KonsultantPlyus".

\section{Information About the Authors}

Vadim N. Perekrestov, Candidate of Juridical Sciences, Magistrate of Judicial District no. 47, Sovetskaya St., 67, 404171 Svetloyarsky District of Volgograd Region, Russian Federation, bulvar04@mail.ru.

Natalya A. Solovyeva, Candidate of Juridical Sciences, Associate Professor, Head of Department of Criminal Procedure and Criminalistics, Volgograd State University, Prosp. Universitetsky, 100, 400062 Volgograd, Russian Federation, solovieva_na@volsu.ru, solovievanataa@gmail.com.

\section{Информация об авторах}

Вадим Николаевич Перекрестов, кандидат юридических наук, мировой судья судебного участка № 47, ул. Советская, 67, 404171 Светлоярский район Волгоградской области, Российская Федерация, bulvar04@mail.ru.

Наталья Алексеевна Соловьева, кандидат юридических наук, доцент, заведующая кафедрой уголовного процесса и криминалистики, Волгоградский государственный университет, просп. Университетский, 100, 400062 г. Волгоград, Российская Федерация, solovieva_na@volsu.ru, solovievanataa@gmail.com. 